\title{
PENGARUH KERAPATAN TANAMAN TERHADAP PRODUKSI BIOMASSA DAN NIRA TIGA VARIETAS SORGUM (Sorghum bicolor (L.) Moench) RATOON I
}

\author{
Desi Anggraeni, Agus Karyanto, Sunyoto \& Muhammad Kamal \\ Jurusan Agroteknologi, Fakultas Pertanian, Universitas Lampung, \\ Jl. Soemantri Brodjonegoro No. 1 Bandar Lampung 35143 \\ E-mail: desianggraeni1@yahoo.com
}

\begin{abstract}
ABSTRAK
Kerapatan tanaman dapat menyebabkan terjadinya kompetisi antar tanaman, sehingga pengaturan kerapatan tanaman yang tepat sangat diperlukan dalam produksi tanaman sorgum.Penelitian ini bertujuan untuk; mengetahuikerapatan tanaman yang terbaik untuk produksi biomassa dan nira pada tanaman sorgum ratoon I,; mengetahuivarietas sorgum ratoon I yang terbaik untuk produksi biomassa dan nira; mengetahuipengaruh interaksi kerapatan tanaman dan varietas terhadap produksi biomassa dan nira.Penelitian ini dilaksanakan di Kebun Percobaaan BPTP (Balai Pengkajian Teknologi Pertanian) Natar, Lampung Selatan, pada bulan September 2013 sampai Desember 2013.Perlakuan disusun secara faktorial dalam Rancangan Acak Kelompok, dengan 3 ulangan.Faktor pertama adalah varietas yang terdiriatas varietas Numbu, Keller, dan Wray.Faktor kedua adalah kerapatanan tanaman yang terdiri atas kerapatan satu, dua, tiga, dan empat tanaman per lubang. Petak percobaan pada penelitian ini berukuran $4 \mathrm{~m} \times 4 \mathrm{~m}$. Hasil penelitian menunjukkan bahwa: kerapatan tiga tanaman per lubang memiliki bobot basah tanaman dan volume nira paling tinggi pada umur $12 \mathrm{mst}$. Perbedaan produksi nira dan bobot tanaman basah antar kerapatan tersebut yaitu 42,66-81,47\% dan 29,84-71,33\%, pada varietas Keller dengan populasi tanaman 187.500 tanaman ha${ }^{1}$ dan jarak tanamnya adalah $80 \times 20 \mathrm{~cm}$; varietas Numbu mampu menghasilkan biomassa dan nira tertinggi pada fase vegetatif, sedangkan varietas Keller menghasilkan biomassa dan nira tertinggi pada fase generatif; kombinasi perlakuan antara kerapatan tanaman dan varietas mempengaruhi produksi biomassa dan nira tanaman sorgum. Kerapatan tiga tanaman per lubang tanam dengan varietas Keller mampu memproduksi biomassa dan nira tertinggi pada sorgum umur 12 mst ratoon I yaitu sebesar $390,00 \mathrm{~g}$ per tanaman dan 85,94 $\mathrm{ml}$ per tanaman, setara dengan 25.350,62 l per hadan 73,125 ton $\mathrm{ha}^{-1}$.
\end{abstract}

Kata kunci: biomassa, kerapatan tanaman, nira, ratoon I, sorgum, varietas.

\section{PENDAHULUAN}

Gardner et.al (1991), menyatakan bahwa peningkatan kerapatan tanaman juga mempunyai arti meningkatkan jumlah tanaman.Pada penelitian ini tanaman sorgum di tanam pada kerapatan yang berbeda, yaitu kerapatan satu, dua, tiga, dan empat tanaman per lubang. Kerapatan tanaman merupakan salah satu faktor penting dalam usaha meningkatkan produksi biomassa dan nira.Pada populasi tinggi, kompetisi antar tanaman dapat terjadi sehingga pertumbuhan dan hasil per individu menjadi berkurang, namun karena jumlah tanaman per hektar bertambah dengan meningkatnya populasi, maka produksi biomassa dan nira per hektar masih dapat meningkat.Suprapto(1985) menyatakan peningkatan kerapatan tanaman per satuan luas sampai batas tertentu dapat meningkatkan hasil pada pertanaman jagung. Akan tetapi, penambahan jumlah tanaman yang selanjutnya akan menurunkan hasil karena terjadi kompetisi hara, radiasi matahari, dan ruang tumbuh.Menurut Lakitan (1993) dikutip oleh Zulkarnain (2005) menyebutkan bahwa padapopulasi tanaman yang lebih sedikit, tingkat persaingan untuk mendapatkan cahaya matahari lebih rendah, akanterjadi peningkatan laju fotosintesis karenaterjadi penangkapan energi cahayamatahari yang lebih besar. Hal ini sangatnyata pada perbedaan jumlah tongkolpada tanaman jagung yang dihasilkan pada jumlah populasi yangberbeda.

Gardner et al. (1991) populasi atau jumlah tanaman setiap satuan luas tanah secara langsung ataupun tidak langsung akan berpengaruh terhadap pertumbuhan dan hasil tanaman.Seperti yang dinyatakan oleh Salisbury and Ross (1985) bahwa populasi yang tinggi menimbulkan persaingan antar tanaman yang menyebabkan batang tanaman diameternya semakin mengecil. Namun, pada penelitian Sumarsono (2008) diketahui bahwa kepadatan populasi tanaman tidak nyata mempengaruhi tinggi tanaman jagung. Sedangkan bobot biji pipilan kering (BPK) jagung nyata dipengaruhi oleh kepadatan populasi tanaman.Bobot BPK per individu tanaman makin rendah dengan meningkatnya kepadatan populasi tanaman. Perbedaan respon ini sebagai akibat 
perbedaan ketersediaan air.Makin tinggi kepadatan populasi tanaman maka ILD tanaman jagung juga makin tinggi.

Produksi biomassa dan nira mempunyai hubungan dengan morfologi dari setiap varietas. Setiap varietas sorgum memiliki respon yang berbeda karena setiap varietas sudah membawa gen bawaan masing-masing, sehingga memiliki kemampuan untuk produksi nira maupun biomassa yang berbeda-beda untuk setiap varietasnya. Penampilan varietas juga berhubungan erat dengan kondisi lingkungan karena karakter mudah dipengaruhi lingkungan. Budiman (2005) dikutip oleh Efendi et al. (2013) yaitu faktor gen merupakan faktor penurunan sifat pada keturunan yang terkandung di dalam genotipe. Informasi genetik pada gen mengendalikan terbentuknya penampakan sifat fisik melalui interaksinya dengan lingkungan.

Tanaman sorgum dapat diratoon atau dapat dipanen lebih dari sekali dalam satu musim tanam dengan hasil yang tidak jauh berbeda.Menurut Alfandi (2006) ratoonmerupakan salah satu cara untuk meningkatkan hasil tanaman per satuan luas lahan dan per satuan waktu. Sehingga, melalui teknik budidaya yang tepat produksi biomassa dan nira sorgum dapat ditingkatkan.Penelitian ini bertujuan untuk:(1) mengetahui kerapatan tanaman yang terbaik untuk produksi biomassa dan nira pada tanaman sorgum ratoon $\mathrm{I}$, (2) mengetahui varietas sorgum ratoon I yang terbaik untuk produksi biomassa dan nira, (3) mengetahui pengaruh interaksi kerapatan tanaman dan varietas terhadap produksi biomassa dan nira.

\section{BAHAN DAN METODE}

Tabel 1. Susunan kombinasi perlakuan tanaman sorgum dalam penelitian

\begin{tabular}{cl}
\hline Perlakuan & \multicolumn{1}{c}{ Keterangan } \\
\hline G1P1 & Varietas Numbu dengan Perlakuan satu tanaman/lubang \\
G1P2 & Varietas Numbu dengan Perlakuan dua tanaman/lubang \\
G1P3 & Vari etas Numbu dengan Perlakuan tiga tanaman/lubang \\
G1P4 & Vari etas Numbu dengan Perlakuan empat tanaman/lubang \\
G2P1 & Varietas Keller dengan Perlakuan satu tanaman/lubang \\
G2P2 & Varietas Keller dengan Perlakuan dua tanaman/lubang \\
G2P3 & Varietas Keller dengan Perlakuan tiga tanaman/lubang \\
G2P4 & Varietas Keller dengan Perlakuan empat tanaman/lubang \\
G3P1 & Varietas Wray dengan Perlakuan satu tanaman/lubang \\
G3P2 & Varietas Wray dengan Perlakuan dua tanaman/lubang \\
G3P3 & Varietas Wray dengan Perlakuan tiga tanaman/lubang \\
G3P4 & Varietas Wray dengan Perlakuan empat tanaman/lubang \\
\hline
\end{tabular}

Penelitian ini dilaksanakan di Kebun Percobaaan BPTP (Balai Pengkajian Teknologi Pertanian) Natar, Lampung Selatan, dan Laboratorium Agronomi, Fakultas Pertanian, Universitas Lampung, pada bulan September 2013 sampai Desember 2013. Bahan yang diperlukan dalampenilitian ini yaitu sorgum manis (Sorghum bicolor (L.) Moench) varietas Numbu, Keller dan Wray; pupuk Urea, SP36, dan KCl. Alat-alat yang digunakan adalah mesin pemeras tebu, sabit, pisau, label, jangka sorong, gelas ukur, oven, koran,meteran, refraktometer dan timbangan digital. Petak percobaan berukuran $4 \times 4$ $\mathrm{m}$ dan sorgum ditanam dengan jarak tanam $80 \times 20 \mathrm{~cm}$, sehingga setiap petak terdiri dari 100 lubang tanam. Populasi per hektar untuk kerapatan satu, dua, tiga, dan empat tanaman per lubang berturut-turut yaitu 62.500 tanaman per ha, 125.000 tanaman per ha, 187.500 tanaman per ha, dan 250.000 tanaman per ha. Perlakuan disusun secara faktorial dalam Rancangan Acak Kelompok dengan 3 ulangan.Faktor pertama adalah kerapatan tanam $(\mathrm{P})$ yang terdiri dari atas 4 taraf, yaitu: satu tanaman per lubang (P1), dua tanaman per lubang (P2), tiga tanaman per lubang (P3), dan empat tanaman per lubang (P4). Faktor kedua adalah varietas sorgum (G) yang terdiri atas 3 taraf, yaitu: varietas Numbu (G1), varietas Keller (G2), varietas Wray (G3). Diperoleh 12 kombinasi perlakuan yang diulang $3 \mathrm{kali}$, sehingga terdapat 36 satuan percobaan (Tabel 1).

Langkah awal penelitian ini, saat pemanenan sorgum tanaman pertama dilakukan pemotongan batang tua $\pm 10-15 \mathrm{~cm}$ di atas permukaan tanah dengan menggunakan sabit.Tunas-tunas baru yang muncul (ratoon) dipelihara dengan baik.Penjarangan, dilakukan terhadap ratoon yang tumbuh dalam pertanaman sorgum sesuai dengan jumlah perlakuan per lubang 
tanam.Pemupukan Urea, SP-36, dan $\mathrm{KCl}$, masingmasing dengan dosis $100,100,150 \mathrm{~kg} \mathrm{ha}^{-1}$. Pemberian pupuk Urea dilakukan sebanyak dua kali. Pupuk diberikan dengan cara larikan terputus. Pemeliharaan pada penelitian ini yaitu mengendalikan OPTdan menyiram. Tanaman sampel dipilih secara acak.Setiap petak dipilih 5 tanaman sampel untukpengamatan biomassa dan 5 tanaman sampel untuk pengamatan nira.Pengamatan ini dilakukan pada umur $6 \mathrm{mst}$ (vegetatif) dan $12 \mathrm{mst}$ (generatif). Pada pengamatan umur 6 dan 12 mst digunakan sampel yang berbeda. Peubah yang diamati dalam penelitian ini meliputi daya tumbuh atau persentase tumbuh ratoon, panjang batang $(\mathrm{cm})$, diameter batang diukur $(\mathrm{cm})$, bobot tanaman basahdiukur ( $\mathrm{g}$ pertanaman dan $\mathrm{kg}$ per petak), bobot tanaman kering (g per tanaman dan $\mathrm{kg}$ per petak), volume nira(ml per tanaman dan 1 per petak), dan kadar gula nira sorgum ( ${ }^{\circ}$ Brix). Nira diperoleh secara mekanik, yaitu digiling menggunakan mesin pemeras tebu,kadar gula diukur dengan menggunakan alat pengukur kadar gula (refraktometer).Homogenitas ragam diuji dengan uji Bartlet, aditivitas data diuji dengan uji Tukey.Bila asumsi terpenuhi data dianalisis dengan analisis
ragam.Perbedaan nilai tengah diuji dengan Uji Beda Nyata Terkecil (BNT) taraf $5 \%$.

\section{HASIL DAN PEMBAHASAN}

Hasil penelitian pengaruh kerapatan tanam dan beberapa varietas sorgum (Sorghum bicolor (L.)Moench) terhadap biomassa dan nira menunjukan bahwa kerapatan tanaman dan varietas berpengaruh nyata. Peningkatan kerapatan tanaman (satu sampai empat tanaman per lubang) menurunkan panjang batang, diameter batang, dan bobot tanaman sorgum per tanaman, dapat dilihat pada Tabel 2, 3, 4, 5, 6, 7 dan 8 . Kerapatan yang tinggi menyulitkan cahaya untuk memasuki ruang tumbuh, daun-daun tanaman sorgum saling menutupi sehingga menyebabkan daun-daun tersebut tidak dapat berfungsi secara optimal dalam berfotosintesis untuk menghasilkan fotosintat yang akan merugikan tanaman itu sendiri. Dengan demikian, tanaman tersebut memiliki batang yang berdiameter kecil dan berdaun sempit yang menyebabkan produksi biomassa dan nira menurun. Menurut Salisbury and Ross (1995) populasi yang tinggi menimbulkan

Tabel 2. Pengaruh kerapatan tanam dan varietas tanaman sorgum terhadap beberapa peubah yang diamati pada tanaman sorgum ratoon I umur 6 mst dan 12 mst (tidak ada interaksi)

\begin{tabular}{|c|c|c|c|c|c|c|c|c|}
\hline & & \multicolumn{7}{|c|}{ Umur Tanaman (mst) } \\
\hline & 6 & 6 & 6 & 12 & 12 & 12 & 12 & 12 \\
\hline Perlakuan & $\begin{array}{l}\text { Panjang } \\
\text { Batang } \\
(\mathrm{cm})\end{array}$ & $\begin{array}{l}\text { Di amater } \\
\text { Batang } \\
(\mathrm{cm})\end{array}$ & $\begin{array}{l}\text { Kadar } \\
\text { Brix } \\
\left({ }^{\circ} \text { Brix }\right)\end{array}$ & $\begin{array}{l}\text { Diamater } \\
\text { Batang } \\
(\mathrm{cm})\end{array}$ & $\begin{array}{c}\text { Bobot } \\
\text { Tanaman } \\
\text { Basah } \\
\text { (g/tanaman })\end{array}$ & $\begin{array}{c}\text { Bobot } \\
\text { Tanaman } \\
\text { Kering } \\
\text { (g/tanaman) }\end{array}$ & $\begin{array}{c}\text { Bobot } \\
\text { Tanaman } \\
\text { Basah } \\
\text { (kg/petak) }\end{array}$ & $\begin{array}{c}\text { Bobot } \\
\text { Tanaman } \\
\text { Kering } \\
\text { (kg/petak) }\end{array}$ \\
\hline \multicolumn{9}{|l|}{$\begin{array}{c}\text { Kerapatan } \\
\text { Tanaman }\end{array}$} \\
\hline 1 & 86,20 a & $1,81 \mathrm{a}$ & $3,81 \mathrm{a}$ & $1,77 \mathrm{a}$ & 700,37 a & $192,00 \mathrm{a}$ & $70,04 \mathrm{c}$ & $19,20 \mathrm{c}$ \\
\hline 2 & $79,45 \mathrm{~b}$ & $1,47 \mathrm{~b}$ & $3,78 \mathrm{a}$ & $1,54 \mathrm{~b}$ & $450,56 \mathrm{~b}$ & $107,86 \mathrm{~b}$ & $90,11 \mathrm{~b}$ & $21,57 \mathrm{bc}$ \\
\hline 3 & $59,57 \mathrm{c}$ & $1,16 \mathrm{c}$ & $3,84 \mathrm{a}$ & $1,28 \mathrm{c}$ & $390,00 \mathrm{~b}$ & $91,05 \mathrm{~b}$ & $117,00 \mathrm{a}$ & $27,32 \mathrm{a}$ \\
\hline 4 & $60,71 \mathrm{c}$ & $1,14 \mathrm{c}$ & $3,89 \mathrm{a}$ & $1,16 \mathrm{~d}$ & $224,72 \mathrm{c}$ & $59,97 \mathrm{c}$ & $898,89 \mathrm{~b}$ & $23,99 \mathrm{ab}$ \\
\hline BNT 0,05 & 4,71 & 0,09 & 0,13 & 0,09 & 91,42 & 19,79 & 19,51 & 4,53 \\
\hline $\begin{array}{l}\text { Varietas } \\
\text { Sorgum }\end{array}$ & & & & & & & & \\
\hline Numbu & $80,65 \mathrm{a}$ & $1,32 \mathrm{~b}$ & 4,38 a & $1,34 \mathrm{~b}$ & 447,48 a & 126,78 a & $92,05 \mathrm{a}$ & 25,09 a \\
\hline Keller & $68,87 \mathrm{~b}$ & $1,38 \mathrm{~b}$ & $3,66 \mathrm{a}$ & $1,59 \mathrm{a}$ & $449,40 \mathrm{a}$ & $113,13 \mathrm{ab}$ & $94,47 \mathrm{a}$ & $23,71 \mathrm{ab}$ \\
\hline Wray & $64,93 \mathrm{~b}$ & $1,48 \mathrm{a}$ & 3,45 a & $1,39 \mathrm{~b}$ & 427,36 a & $98,25 \mathrm{~b}$ & 88,75 a & $20,25 \mathrm{~b}$ \\
\hline BNT 0,05 & 4,09 & 0,09 & 0,12 & 0,09 & 79,17 & 17,14 & 16,89 & 3,92 \\
\hline
\end{tabular}

Keterangan : Angka-angka yang diikuti oleh huruf yang sama pada kolom dan perlakuan yang sama tidak berbeda nyata menurut uji BNT pada taraf 5\% 
Tabel 3. Interaksi kerapatan tanam dan varietassorgum terhadap panjang batang per tanaman umur $12 \mathrm{mst}$

\begin{tabular}{|c|c|c|c|c|}
\hline \multirow[b]{2}{*}{ Varietas } & \multicolumn{4}{|c|}{ Kerapatan Tanaman (Jumlah tanaman per lubang) } \\
\hline & 1 & 2 & 3 & 4 \\
\hline & n.......... & ……… & ….......... & ……… \\
\hline \multirow[t]{2}{*}{ Numbu } & $235,88 \mathrm{c}$ & $239,17 \mathrm{~b}$ & $232,77 \mathrm{~b}$ & $220,28 \mathrm{~b}$ \\
\hline & A & A & A & A \\
\hline \multirow[t]{2}{*}{ Keller } & $318,40 \mathrm{a}$ & 279,45 a & $266,47 \mathrm{a}$ & $272,36 \mathrm{a}$ \\
\hline & A & B & B & B \\
\hline \multirow[t]{2}{*}{ Wray } & $278,11 \mathrm{~b}$ & $282,50 \mathrm{a}$ & $251,49 \mathrm{ab}$ & $238,41 \mathrm{~b}$ \\
\hline & A & A & B & B \\
\hline BNT 0,05 & 20,48 & & & \\
\hline
\end{tabular}

Keterangan: Angka yang diikuti huruf yang sama tidak berbeda nyata menurut uji BNT pada $\alpha 5 \%$, horizontal untuk perbandingan huruf besar dan vertikal untuk perbandingan huruf kecil.

Tabel 4. Interaksi kerapatan tanam dan varietas sorgum terhadap bobot tanaman basah per tanaman pada umur 6 mst

\begin{tabular}{|c|c|c|c|c|}
\hline \multirow[b]{2}{*}{ Varietas } & \multicolumn{4}{|c|}{ Kerapatan Tanaman (Jumlah Tanaman per Lubang) } \\
\hline & 1 & 2 & 3 & 4 \\
\hline Numbu & $\begin{array}{c}294,00 \mathrm{~b} \\
\text { A }\end{array}$ & $\begin{array}{c}229,33 \mathrm{a} \\
\text { B }\end{array}$ & $\begin{array}{c}128,67 \mathrm{a} \\
\mathrm{C}\end{array}$ & $\begin{array}{c}164,50 \mathrm{a} \\
\mathrm{C}\end{array}$ \\
\hline Keller & $\begin{array}{c}355,33 \mathrm{a} \\
\mathrm{A}\end{array}$ & $\begin{array}{c}214,00 \mathrm{a} \\
\mathrm{B}\end{array}$ & $\begin{array}{c}131,33 \text { a } \\
C\end{array}$ & $\begin{array}{c}114,17 \mathrm{~b} \\
\mathrm{C}\end{array}$ \\
\hline Wray & $\begin{array}{c}255,33 \mathrm{~b} \\
\mathrm{~A}\end{array}$ & $\begin{array}{c}202,00 \mathrm{a} \\
\mathrm{B}\end{array}$ & $\begin{array}{c}131,77 \text { a } \\
C\end{array}$ & $\begin{array}{c}93,00 \mathrm{~b} \\
\mathrm{C}\end{array}$ \\
\hline
\end{tabular}

Keterangan: Angka yang diikuti huruf yang sama tidak berbeda nyata menurut uji BNT pada $\alpha 5 \%$, horizontal untuk perbandingan huruf besar dan vertikal untuk perbandingan huruf kecil.

Tabel 5. Interaksi kerapatan tanam dan varietas sorgum terhadap volume nirabatang per tanaman $12 \mathrm{mst}$

\begin{tabular}{|c|c|c|c|c|}
\hline \multirow{3}{*}{ Variet as } & \multicolumn{4}{|c|}{ Kerapatan Tanaman (Jumlah Tanaman per Lubang) } \\
\hline & 1 & 2 & 3 & 4 \\
\hline & \multicolumn{4}{|c|}{ 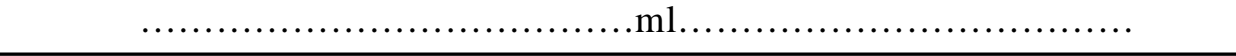 } \\
\hline Numbu & $\begin{array}{c}161,83 \mathrm{~b} \\
\mathrm{~A}\end{array}$ & $\begin{array}{c}121,13 b \\
B\end{array}$ & $\begin{array}{c}90,76 \mathrm{~b} \\
\mathrm{C}\end{array}$ & $\begin{array}{c}61,55 \mathrm{~b} \\
\mathrm{D}\end{array}$ \\
\hline Keller & $\begin{array}{c}223,49 a \\
\text { A }\end{array}$ & $\begin{array}{c}142,16 \mathrm{a} \\
\text { B }\end{array}$ & $\begin{array}{c}135,19 \text { a } \\
\text { C }\end{array}$ & $\begin{array}{c}85,94 \mathrm{a} \\
\mathrm{D}\end{array}$ \\
\hline Wray & $\begin{array}{c}219,33 \mathrm{a} \\
\mathrm{A}\end{array}$ & $\begin{array}{c}155,19 a \\
\text { B }\end{array}$ & $\begin{array}{c}101,41 \mathrm{~b} \\
\mathrm{C}\end{array}$ & $\begin{array}{c}72,83 \mathrm{a} \\
\mathrm{D}\end{array}$ \\
\hline
\end{tabular}

BNT 0,05 $\quad 13.72$

Keterangan: Angka yang diikuti huruf yang sama tidak berbeda nyata menurut uji BNT pada $\alpha 5 \%$, horizontal untuk perbandingan huruf besar dan vertikal untuk perbandingan huruf kecil. 
Tabel 6. Interkasi kerapatan tanam dan varietas sorgum terhadap bobot basah tanaman per petak umur 6 mst.

\begin{tabular}{|c|c|c|c|c|}
\hline \multirow{3}{*}{ Varietas } & \multicolumn{4}{|c|}{ Kerapatan Tanaman (Jumlah Tanaman per Lubang) } \\
\hline & 1 & 2 & 3 & 4 \\
\hline & \multicolumn{4}{|c|}{ 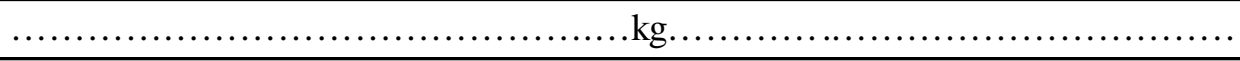 } \\
\hline Numbu & $\begin{array}{c}29,40 \mathrm{a} \\
\mathrm{C}\end{array}$ & $\begin{array}{c}45,87 \text { a } \\
B\end{array}$ & $\begin{array}{c}38,60 \mathrm{a} \\
\mathrm{B}\end{array}$ & $65,80 \mathrm{a}$ \\
\hline Keller & $\begin{array}{c}\mathrm{C} \\
35,53 \mathrm{a} \\
\mathrm{B}\end{array}$ & $\begin{array}{c}\text { B } \\
42,80 \mathrm{a} \\
\mathrm{A}\end{array}$ & $\begin{array}{c}\text { B } \\
39,40 \text { a } \\
\text { A }\end{array}$ & $\begin{array}{c}\text { A } \\
45,66 \text { b } \\
\text { A }\end{array}$ \\
\hline Wray & $\begin{array}{c}25,53 \mathrm{~b} \\
\mathrm{~B}\end{array}$ & $\begin{array}{c}40,40 \mathrm{a} \\
\mathrm{A}\end{array}$ & $\begin{array}{c}39,53 \mathrm{a} \\
\mathrm{A}\end{array}$ & $\begin{array}{c}37,20 \mathrm{~b} \\
\mathrm{~A}\end{array}$ \\
\hline
\end{tabular}

BNT $0,05 \quad 9,08$

Keterangan: Angka yang diikuti huruf yang sama tidak berbeda nyata menurut uji BNT pada $\alpha 5 \%$, horizontal untuk perbandingan huruf besar dan vertikal untuk perbandingan huruf kecil.

Tabel 7. Interkasi kerapatan tanam dan varietas sorgum terhadap bobot kering tanaman per petak umur 6 mst.

\begin{tabular}{|c|c|c|c|c|}
\hline \multirow{3}{*}{ Varietas } & \multicolumn{4}{|c|}{ Kerapatan Tanaman (JumlahTanaman per Lubang ) } \\
\hline & 1 & 2 & 3 & 4 \\
\hline & \multicolumn{4}{|c|}{ 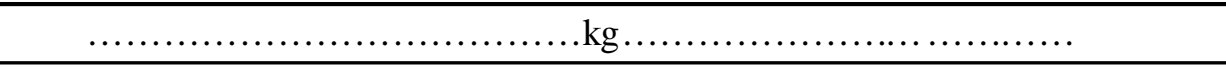 } \\
\hline Numbu & $\begin{array}{c}4,50 \mathrm{a} \\
\mathrm{C}\end{array}$ & $\begin{array}{c}6,87 \mathrm{a} \\
\mathrm{B}\end{array}$ & $\begin{array}{c}6,05 \mathrm{a} \\
\mathrm{B}\end{array}$ & $\begin{array}{c}12,26 \mathrm{a} \\
\mathrm{A}\end{array}$ \\
\hline Keller & $\begin{array}{c}4,87 \mathrm{a} \\
\mathrm{B}\end{array}$ & $\begin{array}{c}6,47 \mathrm{a} \\
\mathrm{A}\end{array}$ & $\begin{array}{c}5,43 \mathrm{a} \\
\mathrm{B}\end{array}$ & $\begin{array}{c}7,55 \mathrm{~b} \\
\mathrm{~A}\end{array}$ \\
\hline Wray & $\begin{array}{c}5,73 \mathrm{a} \\
\mathrm{A}\end{array}$ & $\begin{array}{c}4,93 \mathrm{a} \\
\mathrm{A}\end{array}$ & $\begin{array}{c}5,37 \mathrm{a} \\
\mathrm{A}\end{array}$ & $\begin{array}{c}5,66 \mathrm{~b} \\
\mathrm{~A}\end{array}$ \\
\hline
\end{tabular}

BNT $0,05 \quad 1,95$

Keterangan: Angka yang diikuti huruf yang sama tidak berbeda nyata menurut uji BNT pada $\alpha 5 \%$, horizontal untuk perbandingan huruf besar dan vertikal untuk perbandingan huruf kecil.

Tabel 8. Pengaruh Interkasi kerapatan tanam dan varietas sorgum terhadap per petak umur 6 mst

\begin{tabular}{|c|c|c|c|c|}
\hline \multirow[b]{2}{*}{ Varietas } & \multicolumn{4}{|c|}{ Kerapatan Tanaman (Jumlah Tanaman per Lubang) } \\
\hline & 1 & 2 & 3 & 4 \\
\hline & & $\cdots$ & & \\
\hline Numbu & $54,43 \mathrm{~b}$ & $30,28 \mathrm{~b}$ & $18,87 \mathrm{a}$ & $19,64 \mathrm{a}$ \\
\hline & A & B & C & C \\
\hline Keller & $71,23 \mathrm{a}$ & $31,52 \mathrm{~b}$ & $20,36 \mathrm{a}$ & $23,13 \mathrm{a}$ \\
\hline & A & B & $\mathrm{C}$ & $\mathrm{C}$ \\
\hline Wray & $74,87 \mathrm{a}$ & $38,27 \mathrm{a}$ & $21,57 \mathrm{a}$ & $20,06 \mathrm{a}$ \\
\hline & A & B & $\mathrm{C}$ & $\mathrm{C}$ \\
\hline BNT 0,05 & 4,62 & & & \\
\hline
\end{tabular}

Keterangan: Angka yang diikuti huruf yang sama tidak berbeda nyata menurut uji BNT pada $\alpha 5 \%$, horizontal untuk perbandingan huruf besar dan vertikal untuk perbandingan huruf kecil. 
persaingan antar tanaman yang menyebabkan diameter batang mengecil.

Tanaman sorgum yang ditanam pada kerapatan satu tanaman per lubang memiliki batang terpanjang, sebaliknya pada kerapatan empattanaman per lubang memiliki batang yang cenderung lebih pendek. Pada kerapatan satu tanaman per lubang tanaman sorgum dapat memanfaatkanair, ruang tumbuh, dan cahaya dengan optimal sehingga tanaman dapat tumbuh dan berkembang dengan baik. Oleh karena itu, tanaman sorgum yang ditanam pada kerapatan satu tanaman per lubang memiliki diameter batang paling besar, memiliki bobot tanaman basah dan bobot tanaman kering per tanaman paling besar (Tabel 2, 3, 4, 5, 6, 7 dan 8).

Bobot tanaman basah dan bobot tanaman kering per petak pada fase vegetatif $(6 \mathrm{mst})$ tertinggi yaitu kerapatan empat tanaman per lubang. Sedangkan pada umur 12 mst bobot tanaman basah dan bobot tanaman kering per petak, kerapatan tiga tanaman per lubang tanam memiliki nilai paling tinggi. Perbedaan produksi biomassa karena pengaruh tinggi dan diameter tanaman yang dimiliki dari genotipe dan kerapatan tanaman sorgum berbeda-beda. Besarnya potensi produksi biomassa dan nira sorgum dipengaruhi oleh tinggi tanaman dan diameter tanaman pada umur 6 dan 12 mst. Yang menunjukkan bahwa semakin panjang dan besar diameter tanaman, semakin tinggi produksi biomassa tanaman, begitupun sebaliknya.Hal tersebut dapat dilihat dari panjang tanaman varietas Keller pada umur $12 \mathrm{mst}$, memiliki potensi produksi biomassa paling tinggi yaitu 700,37 gram per tanaman dan 223,49 ml per tanaman, memiliki panjang tanaman terpanjang yaitu $318,40 \mathrm{~cm}$ dan ditunjang dengan diameter batang yang besar yaitu 2,47 $\mathrm{cm}$ (kerapatan satu tanaman per lubang). Sedangkan panjang tanaman sorgum varietas Numbu yaitu hanya sebesar $220,28 \mathrm{~cm}$, dan diameter batangnya yaitu $1,28 \mathrm{~cm}$ (kerapatan empat tanaman per lubang), sehingga berdampak pada rendahnya produksi biomassa dan nira yaitu 224,72 gram per tanaman dan 61,55 ml per tanaman (Tabel 2, 3, 4, 5, 6, 7 dan 8).

Dari hasil penelitian ini diketahui bahwa waktu panen sangat menentukan produksi nira tanaman sorgum, waktu panen yang menghasikan produksi terbaik yaitu pada saat tanaman berumur 12 mst atau tanaman tersebut sudah memasuki fase generatif karena pada saat tanaman masih berumur 6 mst produksi niranya jauh lebih rendah.Rata-rata nilai brix tertinggi dalam penelitian ini hanya sebesar $11,77^{\circ}$ Brix, yang tergolong rendah (Tabel 9). Kadar gula dalam batang sorgum manis ditentukan oleh beberapa gendengan pengaruh waktu dan pewarisan sifat. Kadar gula pada tanaman sorgum mudah sekali mengalami penurunan karena heritabilitas gula dalam batang sorgum tidak tinggi, yang menunjukkan bahwa karakter itu mudah diubah oleh lingkungan.Selain itu, batang sorgum menurun dengan cepat seiring dengan air dalam batang yang menghilang.Jadi, dalam praktik di lapanganpemanenan sorgumharus dilakukan dalam waktu singkat (FAO Corporate Document Repository, 2013).

Kandungan gula dalam penelitian ini tergolong rendah (Tabel 9), jika dibandingkan dengan literatur seperti yang dinyatakan Almodares dan Hadi (2009), kandungan gula dari batang sorgum manis berkisar 14$23{ }^{\circ}$ Brix. Hal ini dikarenakan beberapa faktor salah satunya yaitu adanya waktu tunda giling pada batang sorgum manis, seperti yang diketahui bahwa semakin lama batang disimpan maka brix yang dihasilkan akan semakin menurun, hal ini sesuai dengan pernyataan

Tabel 9. Interaksi kerapatan tanam dan varietas sorgum terhadap nilai brix batangper petak umur $12 \mathrm{mst}$

\begin{tabular}{|c|c|c|c|c|}
\hline \multirow{3}{*}{ Varietas } & \multicolumn{4}{|c|}{ Kerapatan Tanaman (Jumlah Tanaman per Lubang) } \\
\hline & 1 & 2 & 3 & 4 \\
\hline & \multicolumn{4}{|c|}{ 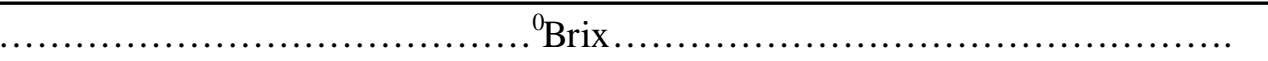 } \\
\hline \multirow[t]{2}{*}{ Numbu } & 7,98 a & $7,28 \mathrm{a}$ & $8,00 \mathrm{a}$ & $7,53 \mathrm{a}$ \\
\hline & $\mathrm{A}$ & A & A & A \\
\hline \multirow[t]{2}{*}{ Keller } & $9,50 \mathrm{ab}$ & $9,99 \mathrm{ab}$ & $11,77 b$ & $8,31 \mathrm{ab}$ \\
\hline & A & $\mathrm{B}$ & $\mathrm{BC}$ & $\mathrm{D}$ \\
\hline \multirow[t]{2}{*}{ Wray } & $10,89 \mathrm{c}$ & $9,78 \mathrm{c}$ & $9,68 \mathrm{c}$ & $7,97 \mathrm{~b}$ \\
\hline & A & B & $\mathrm{BC}$ & $\mathrm{D}$ \\
\hline BNT 0,05 & 0,88 & & & \\
\hline
\end{tabular}

Keterangan: Angka yang diikuti huruf yang sama tidak berbeda nyata menurut uji BNT pada $\alpha 5 \%$, horizontal untuk perbandingan huruf besar dan vertikal untuk perbandingan huruf kecil. 
Risvan (2012) dikutip oleh Putrianti (2013) yang menyatakan keterlambatan waktu giling sangat berpengaruh terhadap tingkat kehilangan gula karena setelah dipotong batang dapat terinfeksi oleh mikroba dan bakteri. Meskipun dalam jumlah kecil keduanya memanfaatkan gula sebagai sumber energinya.Selain waktu tunda giling adanya faktor penyinaran selama batang disimpan juga mempengaruhi penurunan brix.Hal ini sesuai dengan Kawulo (2009) dikutip oleh Putrianti (2013) yang menyatakan bahwa pengaruh sinar matahari selama masa tunggu pengekstraksian mengakibatkan terjadinya proses penguapan batang dan memacu aktifnya ragi- ragi liar dalam proses fermentasi.

Besarnya persentase tumbuh ratoon dari beberapa varietas sorgum manisini menunjukkan bahwa daya ratoon tanaman sorgum cukup baik. Adanya potensi daya ratoon yang baik dapat dimanfaatkan petani dalam menekan biaya tenaga kerja dan benih, waktukarena hanya memerlukan satu kali penanaman dan pengolahan tanah, dapat dipanen lebih dari sekali, maka budi daya sorgum menjadi lebih efisien. Kerapatan tiga tanaman per lubang memiliki bobot tanaman basah dan volume nira paling tinggi pada umur $12 \mathrm{mst}$. Perbedaan produksi nira dan bobot tanaman basah antar kerapatan tersebut yaitu 42,66 - 81,47\% dan 29,84 $71,33 \%$, pada varietas Keller dengan populasi tanaman 187.500 tanaman per ha dan jarak tanamnya adalah $80 \times 20 \mathrm{~cm}$. Kerapatan tanaman yang tinggi akan menguntungkan petani dalam intensifikasi lahan. Kerapatan tiga tanaman per lubang tanam dengan varietas Keller mampu memproduksi biomassa dan nira tertinggi pada sorgum umur 12 mst ratoon I yaitu 390,00 g per tanaman dan $85,94 \mathrm{ml}$ per tanaman setara dengan
25.350, 6201 per hadan 73,125 ton ha ${ }^{-1}$, dapat dilihat pada Tabel 2 dan Tabel 5.Sehingga, kerapatan tiga tanaman per lubang tanam pada sorgum varietas Keller ratoon Iini sangat cocok dibudidayakan petani dalam mengembangkan sorgum sebagai bahan pakan ternak maupun bahan baku industri, terutama industri bahan bakar nabati. Menurut Efendi et al. (2013) kadar etanol pada tanaman sorgum sebesar 40-60\%. Dengan demikian, apabila petani mengembangkan industri etanol maka produksi etanol yang akan diperoleh petani yaitu sebesar 1841,58 1 ha $^{-1}$.

\section{KESIMPULAN}

Berdasarkan hasil penelitian dapat disimpulkan bahwa: kerapatan tiga tanaman per lubang memiliki bobot basah tanaman dan volume nira paling tinggi pada umur 12 mst. Perbedaan produksi nira dan bobot tanaman basah antar kerapatan tersebut yaitu 42,66-81,47\% dan 29,84 - 71,33\%, pada varietas Keller dengan populasi tanaman 187.500 tanaman/ha dan jarak tanamnya adalah $80 \times 20 \mathrm{~cm}$; varietas Numbu mampu menghasilkan biomassa dan nira tertinggi pada fase vegetatif, sedangkan varietas Keller menghasilkan biomassa dan nira tertinggi pada fase generatif.; kombinasi perlakuan antara kerapatan tanaman dan varietas mempengaruhi produksi biomassa dan nira tanaman sorgum. Kerapatan tiga tanaman per lubang tanam dengan varietas Keller mampu memproduksi biomassa dan nira tertinggi pada sorgum umur $12 \mathrm{mst}$ ratoon I yaitu sebesar 390,00 g tanaman ${ }^{-1}$ dan $85,94 \mathrm{ml}$ tanaman $^{-1}$, setara dengan 25.350,62 1 ha $^{-1}$ dan 73,125 ton $\mathrm{ha}^{-1}$ (Tabel 10, Tabel 11).

Tabel 10. Interaksi kerapatan tanam dan varietas sorgum terhadap volume nira batang per petak $12 \mathrm{mst}$

\begin{tabular}{|c|c|c|c|c|}
\hline \multirow[b]{2}{*}{ V arietas } & \multicolumn{4}{|c|}{ Kerapatan Tanaman (Jumlah Tanaman per Lubang) } \\
\hline & 1 & 2 & 3 & 4 \\
\hline & \multicolumn{4}{|c|}{ 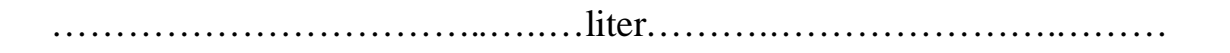 } \\
\hline \multirow[t]{2}{*}{ Numbu } & $16,18 \mathrm{~b}$ & $24,23 \mathrm{~b}$ & $27,23 \mathrm{~b}$ & $24,62 \mathrm{c}$ \\
\hline & B & $\mathrm{AB}$ & A & A \\
\hline \multirow[t]{2}{*}{ Keller } & $22,35 \mathrm{a}$ & 28,43 a & $40,56 \mathrm{a}$ & $34,37 \mathrm{a}$ \\
\hline & $\mathrm{D}$ & $\mathrm{C}$ & A & B \\
\hline \multirow[t]{2}{*}{ Wray } & $21,93 \mathrm{a}$ & $31,04 \mathrm{a}$ & $30,42 \mathrm{~b}$ & $29,13 \mathrm{~b}$ \\
\hline & B & A & A & A \\
\hline
\end{tabular}

BNT 0,05

3,29

Keterangan: Angka yang diikuti huruf yang sama tidak berbeda nyata menurut uji BNT pada $\alpha 5 \%$, horizontal untuk perbandingan huruf besar dan vertikal untuk perbandingan huruf kecil. 
Tabel 11. Interaksi kerapatan tanam dan varietas sorgum terhadap volume nirabatang per tanaman $12 \mathrm{mst}$

\begin{tabular}{|c|c|c|c|c|}
\hline \multirow{3}{*}{ Variet as } & \multicolumn{4}{|c|}{ Kerapatan Tanaman (Jumlah Tanaman per Lubang) } \\
\hline & 1 & 2 & 3 & 4 \\
\hline & \multicolumn{4}{|c|}{ 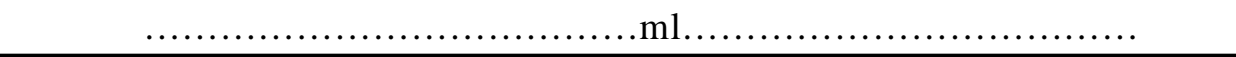 } \\
\hline Numbu & $\begin{array}{c}161,83 \mathrm{~b} \\
\mathrm{~A}\end{array}$ & $\begin{array}{c}121,13 \mathrm{~b} \\
\mathrm{~B}\end{array}$ & $\begin{array}{c}90,76 \mathrm{~b} \\
\mathrm{C}\end{array}$ & $\begin{array}{c}61,55 \mathrm{~b} \\
\mathrm{D}\end{array}$ \\
\hline Keller & $\begin{array}{c}223,49 a \\
\text { A }\end{array}$ & $\begin{array}{c}142,16 \mathrm{a} \\
\mathrm{B}\end{array}$ & $\begin{array}{c}135,19 \mathrm{a} \\
\mathrm{C}\end{array}$ & $\begin{array}{c}85,94 \mathrm{a} \\
\mathrm{D}\end{array}$ \\
\hline Wray & $\begin{array}{c}219,33 \mathrm{a} \\
\mathrm{A}\end{array}$ & $\begin{array}{c}155,19 \mathrm{a} \\
\mathrm{B}\end{array}$ & $\begin{array}{c}101,41 \mathrm{~b} \\
\mathrm{C}\end{array}$ & $\begin{array}{c}72,83 \text { a } \\
\text { D }\end{array}$ \\
\hline
\end{tabular}

BNT 0,05

13.72

Keterangan : Angka-angka yang diikuti oleh huruf yang sama pada kolom dan perlakuan yang sama tidak berbeda nyata menurut uji BNT pada taraf 5\%

\section{DAFTAR PUSTAKA}

Alfandi. 2006. Pengaruh tinggi pemangkasan (ratoon) dan pupuk nitrogen terhadap produksi padi (Oryza sativa L.) kultivar Ciherang. Jurnal Agrijati.2: 1-7.

Almodares A, and M.R. Hadi. 2009. Production of Bioethanol from Sweet Sorghum. A Review.African Journal Agric. Research.4(9): 772-80.

Efendi, R., M. Aqil, dan M. Pabendon. 2013. EvaluasiGenotipe Sorgum Manis(Sorghum bicolor (L.) Moench) Produksi Biomas dan Daya Ratun Tinggi.Jurnal Tanaman Pangan.Vol. 32 No. 2: 116-125.

FAO Corporate Document Repository, 2013.Integrated Energy Systems In China - The Cold Northeastern Region Experience. Natural Resources Management and Environment Department.

Gardner, F.P., R. B. Pearce, and P. R. Michael. 1991. FisiologiTanaman Budidaya, Penterjemah Herawati Susilo. UI Press: Jakarta.
Putrianti, R.D. 2013.Pengaruh Lama Penyimpanan Batang Sorgum Manis (Sorghum bicolor (L.) Moench) Terhadap Rendemen dan Brix Nira yang Dihasilkan. Jurusan Teknologi Pertanian. Fakultas Pertanian. Universitas Hasanuddin: Makassar.Skripsi.

Salisbusry, F.B. dan C.W. Ross, 1985.Plant Physiology.Third Edition.Wadsworth Publishing Company. Belmont: California. 540p.

Sumarsono, S. 2008. Model Hubungan Kepadatan Populasi Tanaman Terhadap Hasil Tanaman Jagung (Zea maysL.). Project Report. Fakultas Peternakan Universitas Diponegoro. 21.687.238.

Suprapto. 1985. Bertanam Jagung. Jakarta : Penebar Swadaya.

Zulkarnain. 2005. Pertumbuhan dan Hasil Selada pada Berbagai Kerapatan Jagung dalam Pola Tumpang Sari. Jurnal Ilmu-ilmu Pertanian.Vol. 1.No. 2. 